\title{
In vitro Binding and Functional Studies of Ac-RYYRIK-ol and Its Derivatives, Novel Partial Agonists of the Nociceptin/Orphanin F/Q Receptor
}

\author{
Özge Gündüz ${ }^{a}$ Ferenc Sipos $^{b}$ Barbara Spagnolod ${ }^{d}$ László Kocsis $^{b, c}$ \\ Anna Magyar $^{b}$ György Orosz ${ }^{c}$ Anna Borsodi ${ }^{a}$ Girolamo Calò $^{d}$ \\ Sándor Benyhe ${ }^{a}$ \\ anstitute of Biochemistry, Biological Research Center, Hungarian Academy of Sciences, Szeged, \\ ${ }^{\mathrm{b}}$ Research Group of Peptide Chemistry, Hungarian Academy of Sciences, Budapest, and \\ ${ }^{\mathrm{C}}$ Reanal Finechemical Co., Budapest, Hungary; ${ }^{\mathrm{d}}$ Department of Experimental and Clinical Medicine, \\ Section of Pharmacology and Neuroscience Center, University of Ferrara, Ferrara, Italy
}

\section{Key Words}

Nociceptin/orphanin FQ • NOP receptor • Hexapeptides •

Ac-RYYRIK-ol · Partial agonist $\cdot$ Radioligand binding $\cdot$

$\left.{ }^{[35} \mathrm{S}\right] \mathrm{GTP} \gamma \mathrm{S}$ binding $\cdot$ Bioassay

\begin{abstract}
Following the discovery of nociceptin/orphanin FQ (N/OFQ) peptide receptor (NOP) and its endogenous ligand, an extensive search has started to find selective agonists and antagonists targeting this novel receptor-ligand system due to their therapeutic potentials. By the help of the combinatorial chemistry a series of hexapeptides with a general formula of Ac-RYY-R/K-W/I-R/K-NH $\mathrm{N}_{2}$ having high NOP receptor affinity and selectivity were identified. On the basis of this information we developed a number of novel compounds. The detailed structure-activity studies on the partial agonist Ac-RYYRIK- $\mathrm{NH}_{2}$ are reported in this communication. Besides the modifications on $\mathrm{N}$ - and C-terminal, Arg-Cit exchange was performed on the template structure. The novel hexapeptides were analyzed in radioligand binding, functional biochemical $\left.{ }^{35} \mathrm{~S}\right]$ GTP $\gamma S$ binding assays by using membranes from rat brains and Chinese hamster ovary cells expressing human NOP receptor. The agonist/antagonist properties
\end{abstract}

were also tested on in the mouse vas deferens bioassay. C-terminal modification yielded a high affinity, selective and potent NOP ligand (Ac-RYYRIK-ol) with a partial agonist property. Several analogs of this compound were synthesized. The presence of the positively charged arginine resi-

\begin{tabular}{ll}
\hline Abbreviations used in this paper \\
\hline Fmoc & 9-Fluoroenyl-methyloxycarbonyl \\
Boc & tert-Butyloxycarbonyl \\
Ac & Acetyl \\
ClAc & Chloro-acetyl \\
Bz & Benzoyl \\
Piv & Pivaloyl \\
For & Formyl \\
Ms & Mezyl \\
DBU & 1,8-Diazabicyclo[5.4.0]-undec-7-en \\
DIPCI & Diizopropylcarbodiimide \\
DIEA & N,N-Diisopropylethylamine \\
HOBt & 1-Hydroxybenzotriazole \\
HBTU & O-(benzotriazol-1-yl)-N,N,N',N'-tetramethyluronium- \\
& hexafluorophosphate \\
N/OFQ & Phe-Gly-Gly-Phe-Thr-Gly-Ala-Arg-Lys-Ser-Ala-Arg- \\
& Lys-Leu-Ala-Asn-Gln) \\
UFP-101 & [Nphe ${ }^{1}$, Arg $^{14}{ }^{14}$ Lys ${ }^{15}$ ]N/OFQ-NH \\
\hline
\end{tabular}

\section{KARGER}

Fax +41613061234 E-Mail karger@karger.ch www.karger.com
(C) 2006 S. Karger AG, Basel

$1424-862 X / 06 / 0152-0091 \$ 23.50 / 0$

Accessible online at:

www.karger.com/nsg
Özge Gündüz

Institute of Biochemistry, Biological Research Center

Hungarian Academy of Sciences, PO Box 521

HU-6701 Szeged (Hungary)

Tel. +36 62432 099, Fax +36 62433 432, E-Mail ozge@nucleus.szbk.u-szeged.hu 
due at the first position turned out to be crucial for the biological activity of the hexapeptide. The $\mathrm{N}$-terminal modifications with various acyl groups (ClAc, pivaloyl, formyl, benzoyl, mesyl) decreased the affinity of the ligand towards the receptor and the intrinsic activity for stimulating the G-protein activation was also decreased. The structureactivity studies on the hexapeptide derivatives provided some basic information on the structural requirements for receptor binding and activation.

Copyright $\odot 2006$ S. Karger AG, Basel

\section{Introduction}

In 1994, nociceptin/orphanin FQ (N/OFQ) peptide (NOP) receptor was cloned from human as an orphan Gprotein coupled receptor (oGPCR) [1]. Despite its high homology with the opioid receptors, the binding affinity of the known opioid ligands to this site was poor. NOP receptor was deorphanized by the discovery of its endogenous ligand, N/OFQ $[2,3]$. This was the first successful example of the reverse pharmacology approach [4]. The heptadecapeptide N/OFQ and the NOP receptor constitute a peptide receptor-ligand system which is widely distributed in the central and peripheral nervous system, as well as in the immune system [5]. Accordingly, N/OFQ elicits a broad range of biological effects such as modulation of pain transmission, of anxiety and response to stress, learning and memory, drug reward, food intake, and locomotor activity. In addition, N/OFQ also controls some functions of the renal, cardiovascular, respiratory, and gastrointestinal systems (see for reviews: $[6,7]$ ). Briefly, NOP receptor agonists can serve as anxiolytics, stimulants of food intake, antitussives, spinal analgesics, suppressants of drug abuse, and can be used for the management of hyponatremic and water-retaining syndromes, while NOP antagonists can be candidates as analgesics (alone or in combination with opioids), antidepressants, anorectics, or as nootropic agents [8]. Moreover, recent data indicate that NOP antagonists are worthy of development as innovative antiparkinson drugs [9]. Thus, the NOP receptor represents an interesting molecular target for the development of novel therapeutics. This makes the system highly attractive for drug development purposes [8]. Until now, the best available ligands used as pharmacological tools for investigating the consequences of NOP receptor selective activation or blockage are: among agonists the peptide UFP-102 $\left[(\mathrm{pF}) \mathrm{Phe}^{4}, \mathrm{Arg}^{14}, \mathrm{Lys}^{15}\right]-\mathrm{N} / \mathrm{OFQ}-\mathrm{NH}_{2}$ [10] and the nonpeptide Ro 64-6198 [11] and among antagonists the pep- tide UFP-101 ([Nphe $\left.\left.{ }^{1}, \mathrm{Arg}^{14}{ }^{14} \mathrm{Lys}^{15}\right] \mathrm{N} / \mathrm{OFQ}-\mathrm{NH}_{2}\right)[12,13]$ and the non-peptides J-113397 [14] and SB-612111 [15]. In addition to these compounds, in 1997 a series of hexapeptides with the general formula of Ac-RYY-R/K-W/I-R/K$\mathrm{NH}_{2}$ having high affinity and selectivity for the NOP receptor were identified from a synthetic combinatorial hexapeptide library containing about 52 million compounds [16]. These hexapeptides were reported to behave as partial agonists at recombinant NOP receptors expressed in CHO cells (measured by $\left[{ }^{35} \mathrm{~S}\right] \mathrm{GTP} \gamma \mathrm{S}$ binding and cAMP accumulation assays) and at native NOP receptor expressed in the mouse vas deferens ( $\mathrm{mVD}$ bioassay) [16]. Structure activity studies were performed by using the Ac-RYYR-I/W-K-NH${ }_{2}$ sequence as a template. The binding affinity was decreased by the head-to-tail cyclization of Ac-RYYRWK-NH $\mathrm{N}_{2}$ [17] and increased by $\mathrm{N}$-terminal acylation with a pentanoyl group [18] or the replacement of the $\mathrm{Tyr}^{2,3}$ residues with (pF)Phe [19]. A NOP receptor agonist was generated by N-terminal alkylation of the central core YYRW with groups bearing a guanidine function [20]. Moreover, a NOP selective partial agonist with high affinity, metabolic stability and in vivo duration of action was generated by addition of a polylysine sequence to the C-terminal (Ac-RYYRWKKKKKKK-NH ${ }_{2}$ namely ZP-120) [21-23]. Finally, a high affinity NOP receptor ligand with antagonist properties was prepared by substituting the C-terminal amide with an alcoholic function, resulting in Ac-RYYRIK-ol [24]. This hexapeptide alcohol was further characterized by in vitro and in vivo approaches and turned out to be a low efficacy NOP receptor agonist with high potency, selectivity of action, metabolic stability and in vivo activity [25].

In the present study, it was aimed to determine structural requirements of the hexapeptide alcohol acting in the nociceptin system. To reach this goal, structure-activity studies were done by systematic replacement of arginine with citrulline, and by modifying the $\mathrm{N}$-terminal of the hexapeptide alcohol. The N-terminal chemical modifications were performed in order to determine its role in binding process and to which extend its elimination or modification of its chemical character (by several substitutions) is tolerated for the biological activity. The newly synthesized hexapeptides were characterized by in vitro receptor binding and functional biochemical GTP $\gamma\left[{ }^{35} \mathrm{~S}\right]$ binding assays on rat brain membranes and human recombinant NOP receptors expressed in Chinese hamster ovary cells $\left(\mathrm{CHO}_{\mathrm{hNOP}}\right)$ as well as by pharmacological assays on the mouse vas deferens. 


\section{Materials and Methods}

\section{Chemicals}

[leucyl- ${ }^{3} \mathrm{H}$ ]N/OFQ $(160 \mathrm{Ci} / \mathrm{mmol})$ was purchased from Amersham, UK. $\left[{ }^{3} \mathrm{H}\right]$ naloxone $(28 \mathrm{Ci} / \mathrm{mmol})$ was prepared as described [26]. Guanosine- $5^{\prime}-\left[\gamma^{-}{ }^{35} \mathrm{~S}\right]$-triphosphate $(1,204 \mathrm{Ci} / \mathrm{mmol})$ was purchased from the Isotope Institute Ltd. (Budapest, Hungary) and from Amersham, UK with a specific activity of 1,033 Ci/ mmol. N/OFQ and N/OFQ(1-13) $\mathrm{NH}_{2}$ were purchased from Bachem, Bubendorf, Switzerland. UFP-101 ([Nphe $\left.{ }^{1}, \mathrm{Arg}^{14}{ }^{14} \mathrm{Lys}^{15}\right]$ $\mathrm{N} / \mathrm{OFQ}-\mathrm{NH}_{2}$ ) was kindly provided by Dr. Guerrini (Department of Pharmaceutical Sciences, University of Ferrara, Ferrara, Italy) [13], $\mathrm{MgCl}_{2}, \mathrm{KCl}$, ethylenediamine-tetraacetic acid (EDTA), polyethyleneimine (PEI), Tris-hydroxymethyl-aminomethane, protease-free bovine serum albumin (protease-free BSA, fraction V), guanosine 5'-diphospate (GDP), guanosine-5'-o-(3-thiotriphosphate) GTP $\gamma \mathrm{S}$ were products of Sigma-Aldrich. All (Fmoc)-protected amino acids, HOBt were from Novabiochem (Switzerland). DIPCI was the product of Fluka (Switzerland). Rink-amide resin and chloro-trityl resin were obtained from Reanal (Hungary). All the solvents and other reagents used in the synthesis and purification were from Fluka.

\section{Peptide Synthesis}

The Ac-Arg-Tyr-Tyr-Arg-Ile-Lys- $\mathrm{NH}_{2}$ and Ac-Arg-Tyr-TyrArg-Ile-Lys-ol derivatives - containing citrullin instead of arginine - were synthesized manually by SPPS, according to Fmoc strategy using Rink amide [27] and chloro-trityl resin [28] as a support. Fmoc-Lys(Boc)-ol [24] was synthesized from FmocLys(Boc)- $\mathrm{OH}$ through its mixed anhydride using sodium borohydride at $0^{\circ} \mathrm{C}$. Fmoc-Lys(Boc)-OH was attached to Rink amide resin in DCM using DIPCI and HOBt. The protocol of the peptide synthesis was the following: (1) DMF washing $(3 \times 1 \mathrm{~min})$; (2) deprotection with $2 \%$ DBU, $2 \%$ piperidine in DMF (20 min); (3) DMF washing $(6 \times 1 \mathrm{~min})$; (4) coupling of Fmoc amino acid: DIPCI: HOBt $=2: 2: 2.2$ or Fmoc amino acid: HBTU: DIEA $=$ 2: 1.9: 4: 9 in DMF (60 min), and (5) DMF washing ( $3 \times 1 \mathrm{~min})$. The N-terminal amino groups of the peptides were acylated by different carbonic acid 4-nitrophenyl esters (Ac-, ClAc-, Bz-, Piv-, For-ONp) and mesyl-chloride in the presence of DIEA. The peptide-resin bond was cleaved and the protecting groups were removed by hydrogen fluoride at $0^{\circ} \mathrm{C}$ for $30 \mathrm{~min}$ in the presence of $10 \%$ anisole. The crude products were purified by reversedphase chromatography on a Vydac C18 column (15-20 $\mu \mathrm{m}, 25 \times$ $480 \mathrm{~mm}$, Pharmacia FPLC system) using an acetonitrile $(0.036 \%$ trifluoroacetic acid) - water (0.045\% trifluoroacetic acid) solvent systems. The structure of the peptides ( $>95 \%$ according to HPLC analysis) was proved by matrix-assisted laser desorption/ionization (MALDI) mass spectrometry.

\section{Animals}

Inbred Wistar rats (Animal House of the Biological Research Center, Szeged, Hungary) were used throughout this study. Rats were kept in groups of four, allowed free access to food and water and maintained on a 12/12-hour light/dark cycle until the time of sacrifice. Animals were treated according to the European Communities Council Directives (86/609/ECC) and the Hungarian Act for the Protection of Animals in Research (XXVIII.tv. 32.\$). For the isolated tissue assay male Swiss mice weighing 20-25 g were used throughout the studies (Morini, Reggio Emilia, Italy).
Mice were handled according to guidelines published in the European Communities Council directives (86/609/EEC) and Italian national regulations (D.L. 116/92). They were housed in 425 $\times 266 \times 155-\mathrm{mm}$ cages (Techniplast, Milan, Italy), 8 animals/ cage, under standard conditions $\left(22^{\circ} \mathrm{C}, 55 \%\right.$ humidity, 12 -hour light/dark cycle, lights on at 7:00 a.m.) with food (MIL, standard diet; Morini, Reggio Emilia, Italy) and water ad libitum for at least 3 days before the experiments began.

\section{Membrane Preparation}

Crude brain membrane from Wistar rats was prepared as previously described $[24,29]$. Briefly, rats were decapitated and the brains without cerebellum were quickly removed and washed several times with chilled $50 \mathrm{~mm}$ Tris-HCl buffer ( $\mathrm{pH}$ 7.4). Weighed tissues were homogenized using a Braun Teflon-glass homogenizer (10-15 strokes) and filtered through four layers of gauze to remove large aggregates. The homogenate was centrifuged at $40,000 \mathrm{~g}$ for $20 \mathrm{~min}$ at $4^{\circ} \mathrm{C}$ and the resulting pellet was resuspended in fresh buffer and incubated for $30 \mathrm{~min}$ at $37^{\circ} \mathrm{C}$. The centrifugation step was repeated, and the final pellets were resuspended in $50 \mathrm{~mm}$ Tris- $\mathrm{HCl}$ buffer ( $\mathrm{pH} 7.4$ ) containing $0.32 \mathrm{M}$ sucrose and stored at $-70^{\circ} \mathrm{C}$ until use. Before use membranes were thawed, washed by centrifugation to remove sucrose and used immediately in the binding assays.

\section{$\mathrm{CHO}_{h N O P}$ Cells and Crude Membrane Fraction}

Chinese hamster ovary (CHO) cells stably expressing the human NOP receptor protein were kindly obtained from J.C. Meunier, Toulouse, France. Cells were cultured in a medium containing Nut Mix F-12 (HAM) with l-glutamine (GIBCO-Invitrogen) and $25 \mathrm{~mm}$ Hepes, 10\% FCS, $100 \mathrm{UI} / \mathrm{ml}$ penicillin, $100 \mu \mathrm{g} / \mathrm{ml}$ streptomycin, and $0.4 \mathrm{mg} / \mathrm{ml} \mathrm{G} 418$ at $37^{\circ} \mathrm{C}$ in a humidified atmosphere consisting of $5 \% \mathrm{CO}_{2}$ and $95 \%$ air. Cells were collected with trypsin solution in PBS containing $0.05 \%$ trypsin and $0.02 \%$ EDTA, and sub-cultured twice a week. Cells were harvested by washing twice with ice-cold PBS, frozen at $-70^{\circ} \mathrm{C}$ for $2 \mathrm{~h}$ to facilitate cell disruption by water crystallization and homogenized in $50 \mathrm{mM}$ Tris- $\mathrm{HCl}$ (pH 7.4) buffer with a glass/glass hand homogenizer (Wheaton USA). Then centrifuged at 3,000 rpm (Sorvall RC5C centrifuge, SS34 rotor) for $10 \mathrm{~min}$ at $4^{\circ} \mathrm{C}$ and the collected pellets were homogenized in $50 \mathrm{mM}$ Tris- $\mathrm{HCl}$ (pH 7.4) buffer with a glass/glass hand homogenizer. Homogenates were centrifuged two times at $18,000 \mathrm{rpm}$ for $20 \mathrm{~min}$ at $4^{\circ} \mathrm{C}$. Pellets were suspended in Tris- $\mathrm{HCl}$ ( $\mathrm{pH} 7.4$ ) buffer and following the protein determination the membrane preparation was aliquotted $(0.3-0.4 \mathrm{mg} / \mathrm{ml}$ protein per series) and stored at $-70^{\circ} \mathrm{C}$ until use. For the GTP $\gamma S$ binding assays the same procedure was followed, all the pellets were suspended in TEM (50 mM Tris, 1 mM EGTA, $5 \mathrm{~mm} \mathrm{MgCl}$ ) $\mathrm{pH} 7.4$ buffer. At the end the membrane preparation was aliquotted $(\sim 240 \mu \mathrm{g}$ protein per series, $\sim 10 \mu \mathrm{g}$ protein/sample) and stored in the same way.

\section{Competition Binding Assay}

Aliquots of frozen rat brain membranes were thawed, washed by centrifugation $\left(18,000 \mathrm{rpm}, 20 \mathrm{~min},+4^{\circ} \mathrm{C}\right)$ and pellets were suspended in $50 \mathrm{~mm}$ Tris-HCl buffer ( $\mathrm{pH} 7.4$ ) up to $0.3-0.4 \mathrm{mg} / \mathrm{ml}$ protein. Aliquots of $\mathrm{CHO}_{\mathrm{hNOP}}$ membranes were thawed and homogenized with a syringe and used directly in the binding assay. Membranes were incubated with gentle shaking for $1 \mathrm{~h}$, $24^{\circ} \mathrm{C}$ in a final volume of $1 \mathrm{ml}$ with: unlabelled compounds 
$\left(10^{-5}\right.$ to $\left.10^{-11} \mathrm{M}\right)$, and $\sim 0.05 \mathrm{~nm}\left[\right.$ leucyl- $\left.{ }^{3} \mathrm{H}\right] \mathrm{N} / \mathrm{OFQ}(160 \mathrm{Ci} / \mathrm{mmol}$, Amersham) which was prepared in $1 \mathrm{mg} / \mathrm{ml}$ protease-free bovine serum albumin solution. Nonspecific binding was determined in the presence of $1 \mu \mathrm{M}$ of unlabelled N/OFQ. The reaction was terminated by rapid filtration under vacuum (Brandel M24R Cell Harvester), and washed three times with $5 \mathrm{ml}$ ice-cold $50 \mathrm{~mm}$ Tris-HCl (pH 7.4) buffer through Whatman GF/C glass fiber filters presoaked in $0.3 \%$ Polyethyleneimine (PEI) solution ( $\mathrm{pH} \mathrm{10)}$ for $30 \mathrm{~min}$. After filtration filter disks were dried and bound radioactivity was measured in UltimaGolda scintillation cocktail using a Packard Tricarb 2300TR Liquid Scintillation Analyzer. Receptor binding experiments were performed in duplicates and repeated at least 3 times. Protein concentration was measured by the Bradford method with bovine serum albumin as standard [30].

\section{$\left[{ }^{35}\right.$ S]GTP $\gamma$ S-Binding Assay}

Membrane fractions $(\sim 10 \mu \mathrm{g}$ of protein/sample) were incubated at $30^{\circ} \mathrm{C}$ for $60 \mathrm{~min}$ in Tris-EGTA buffer $(50 \mathrm{mM}$ Tris- $\mathrm{HCl}$, $1 \mathrm{~mm}$ EGTA, $3 \mathrm{mM} \mathrm{MgCl}_{2}, 100 \mathrm{mM} \mathrm{NaCl}, \mathrm{pH}$ 7.4) containing $\left.{ }^{35} \mathrm{~S}\right] \mathrm{GTP} \gamma \mathrm{S}(0.05 \mathrm{nM})$ and increasing concentrations $\left(10^{-9}-10^{-5} \mathrm{M}\right)$ of peptides (for concentration response curves) and various concentrations $\left(10^{-8}, 3 \times 10^{-8}, 10^{-7}\right)$ of Ac-RYYRIK-ol (for Schild plot analyses) tested in the presence of $30 \mu \mathrm{M}$ GDP in a final volume of $1 \mathrm{ml}$. Total binding was measured in the absence of the tested compound, nonspecific binding was determined in the presence of $10 \mu \mathrm{M}$ unlabeled GTP $\gamma \mathrm{S}$ and subtracted from total binding to calculate the specific binding. The reaction was started by addition of $\left[{ }^{35} \mathrm{~S}\right] \mathrm{GTP} \gamma \mathrm{S}$ and terminated by filtrating the samples through Whatman GF/B glass-fiber filters. Filters were washed three times with ice-cold $50 \mathrm{~mm}$ Tris- $\mathrm{HCl}$ buffer $(\mathrm{pH} 7.4)$ using Brandel M24R Cell Harvester, then dried, and bound radioactivity was detected in UltimaGoldy scintillation cocktail (Packard). $\left[{ }^{35} \mathrm{~S}\right] \mathrm{GTP} \gamma \mathrm{S}$-binding experiments were performed in triplicates and repeated at least three times.

\section{Mouse Vas Deferens Bioassay}

The mouse vas deferens tissues were isolated from male Swiss mice (20-25 g, Morini, Reggio Emilia, Italy) and prepared accordingly to Calo et al. [31]. Tissues were suspended in $5 \mathrm{ml}$ organ bath containing Krebs buffer (in $\mathrm{mM} 118.1 \mathrm{NaCl}, 4.7 \mathrm{KCl}, 1.8$ $\mathrm{CaCl}_{2} \cdot 2 \mathrm{H}_{2} \mathrm{O}, 1.2 \mathrm{KH}_{2} \mathrm{PO}_{4}, 25 \mathrm{NaHCO}_{3}$, and 5 glucose) at $33^{\circ} \mathrm{C}$ and incessantly gassed with $5 \% \mathrm{CO}_{2}$ and $95 \% \mathrm{O}_{2}$. A resting tension of $0.3 \mathrm{~g}$ was applied. The mouse vas deferens tissues were continuously stimulated through two platinum ring electrodes with supramaximal voltage rectangular pulses of $1 \mathrm{~ms}$ duration and $0.05 \mathrm{~Hz}$ frequency. Electrically evoked contractions (twitches) were measured isotonically with a strain gauge transducer (Basile 7006) and recorded with the PC based acquisition system Power Lab (USA). Following an equilibration period of about $60 \mathrm{~min}$, the contractions induced by electrical field stimulation were stable and cumulative concentration-response curves to N/OFQ were performed ( $0.5 \mathrm{log}$ unit steps) in the absence or in the presence (30 min preincubation time) of increasing concentrations of hexapeptides $(10-1,000 \mathrm{nM})$.

\section{Data Analysis}

All data are expressed as means \pm SEM of at least 3 experiments. All the binding experiments were performed in duplicates and the $\left[{ }^{35} \mathrm{~S}\right] \mathrm{GTP} \gamma \mathrm{S}$ binding assays were performed in triplicates.
Data was analyzed by GraphPad Prism (version 3.0 San Diego, Calif., USA). Displacement curves were fitted by non-linear regression using the one-site competition fitting option. The equilibrium inhibition constant $\left(\mathrm{K}_{\mathrm{i}}\right.$ value) was calculated according to the Cheng-Prusoff equation [32]. $\mathrm{pK}_{\mathrm{i}}$ is the antilogarithm of the $\mathrm{K}_{\mathrm{i}}$ values obtained after the calculations. $\left[{ }^{35} \mathrm{~S}\right] \mathrm{GTP} \gamma \mathrm{S}$ binding data were analyzed by sigmoid dose-response curve fit option of Prism 3.0. Stimulation is given as percent of the specific $\left[{ }^{35} \mathrm{~S}\right] \mathrm{GTP} \gamma \mathrm{S}$ binding observed in the absence of receptor ligands (basal activity). Agonist potencies were expressed as $\mathrm{pEC}_{50}$, which is the negative logarithm to base 10 of the agonist molar concentration that produces $50 \%$ of the maximal possible effect of that agonist. The maximal stimulation of $\left[{ }^{35} \mathrm{~S}\right] \mathrm{GTP} \gamma \mathrm{S}$ over the basal and the inhibition percentage of the control twitch that an agonist can elicit in a given tissue/preparation is expressed as $\mathrm{E}_{\max }$. Antagonist potencies were expressed as $\mathrm{pA}_{2}$ which is the negative logarithm to the base 10 of the antagonist molar concentration that makes it necessary to double the agonist concentration to elicit the original submaximal response [33] and were calculated by Schild's linear regression, that correlates the log of concentrations of antagonist (x-axis) to the log of (CR-1) y-axis, where CR is the ratio between the $\mathrm{EC}_{50}(\mathrm{nM})$ values of the agonist in the presence and absence of antagonist. If the slope of the regression line is not significantly different from the unity, the value of $\mathrm{x}$ for $\mathrm{y}=$ 0 represents the $\mathrm{pA}_{2}$ value. The antagonist potencies of the modified hexapeptides were calculated with a single concentration by the Gaddum Schild Equation $\left(\mathrm{pA}_{2}=-\log \{(\mathrm{CR}-1) /[\right.$ Antagonist $\left.]\}\right)$ and represented as $\mathrm{pK}_{\mathrm{B}}$ values.

\section{Results}

\section{Peptide Synthesis}

Ac-Arg-Tyr-Tyr-Arg-Ile-Lys-ol derivatives containing variations of acyl groups (ClAc-, Bz-, Piv-, For-, Mz-) on the N-terminal part of the peptide and containing systematic replacement of Arg with Cit were synthesized. Some control peptides were also prepared (Ac-Arg-TyrTyr-Arg-Ile-Lys-NH ${ }_{2}$, Ac-Arg-Tyr-Tyr-Arg-Ile-Lys-ol, HArg-Tyr-Tyr-Arg-Ile-Lys-ol). Solid-phase peptide synthesis method according to Fmoc strategy on Rink-amide and chloro-trityl resins was used. The products were analyzed by RP-HPLC and the structures were confirmed by electrospray mass spectrometry.

\section{Receptor Binding Experiments}

Receptor binding experiments were performed with [leucyl- $\left.{ }^{3} \mathrm{H}\right] \mathrm{N} / \mathrm{OFQ}$ on membranes from rat brain and cultured cells transfected with human NOP receptor. The parent compound Ac-RYYRIK-NH $\mathrm{N}_{2}$ and its newly synthesized derivative Ac-RYYRIK-ol, the Arg-Cit exchanged as well as N-terminally modified ligands, were able to displace [leucyl- $\left.{ }^{3} \mathrm{H}\right] \mathrm{N} / \mathrm{OFQ}$ binding with varying affinities (table 1). Heterologous competition curves for 


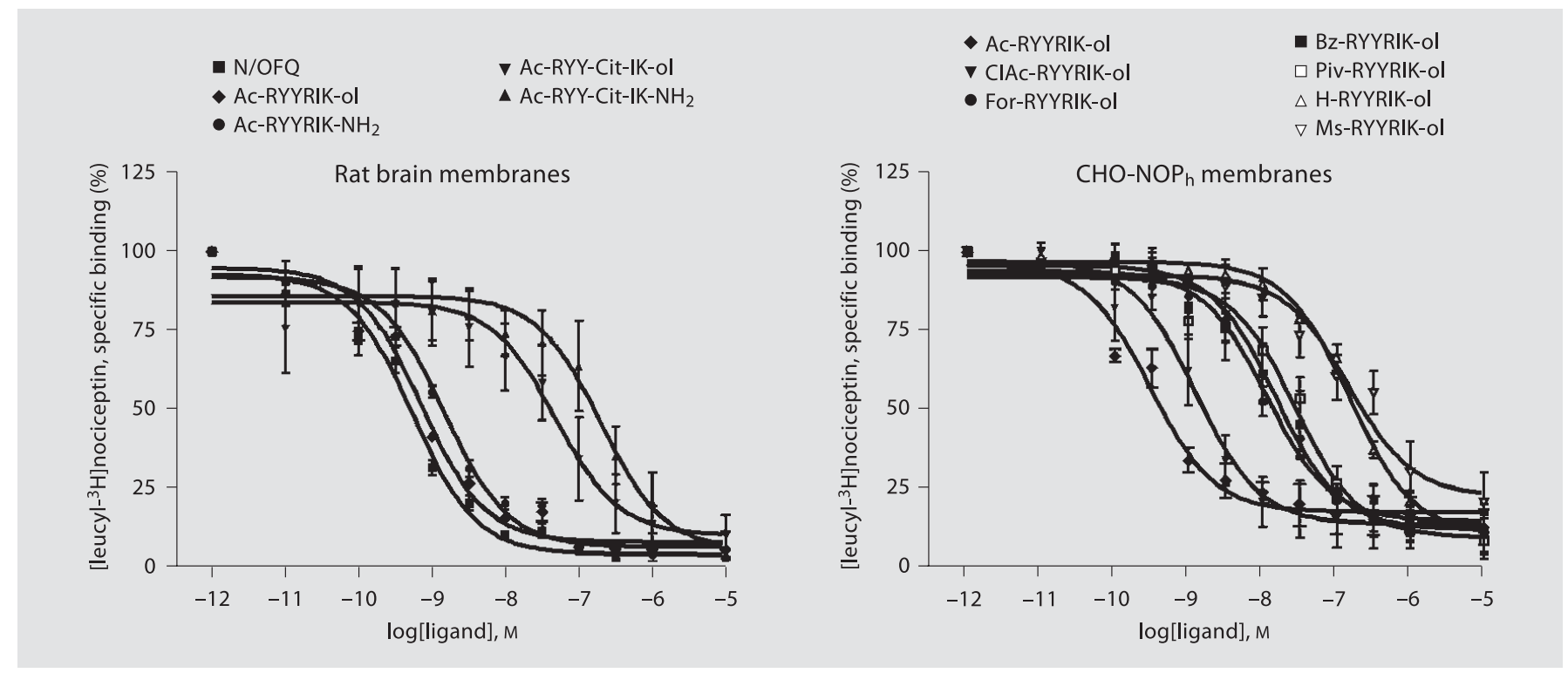

Fig. 1. Equilibrium competition binding with $\left[\right.$ leucyl $\left.-{ }^{3} \mathrm{H}\right] \mathrm{N} / \mathrm{OFQ}(\sim 0.05 \mathrm{nM})$ incubated in the presence of the hexapeptides $\left(10^{-5}\right.$ to $\left.10^{-11} \mathrm{M}\right)$ for $1 \mathrm{~h}$ at $24^{\circ} \mathrm{C}$ with gentle shaking. The peptides are shown according to their rank order of affinity. Left panel: Displacement curves for C-terminally modified and Arg/Cit replaced ligands on native NOP receptors of rat brain membrain. Right panel: Displacement curves for N-terminally modified ligands on $\mathrm{CHO}-\mathrm{NOP}_{\mathrm{h}}$. Points represent the means \pm SEM of at least 3 different experiments each performed in duplicate.

Table 1. Displacement binding data of the hexapeptides in membranes from rat brain and Chinese hamster ovary cells expressing the human NOP receptor

\begin{tabular}{|c|c|c|}
\hline \multirow[t]{2}{*}{ Peptides } & \multicolumn{2}{|l|}{$\mathrm{pK}_{\mathrm{i}} \pm \mathrm{SEM}$} \\
\hline & rat brain & $\mathrm{CHO}_{\mathrm{hNOP}}$ \\
\hline N/OFQ & $9.29 \pm 0.06$ & $9.20 \pm 0.06$ \\
\hline $\mathrm{N} / \mathrm{OFQ}(1-13) \mathrm{NH}_{2}$ & $9.37 \pm 0.07$ & $9.71 \pm 0.09$ \\
\hline Ac-RYYRIK- $\mathrm{NH}_{2}$ 'parent compound' & $8.80 \pm 0.04$ & $9.16 \pm 0.04$ \\
\hline Ac-RYYRIK-ol & $9.10 \pm 0.04$ & $9.39 \pm 0.06$ \\
\hline Ac-Cit-YY-Cit-IK-NH ${ }_{2}$ & $<5$ & $<5$ \\
\hline Ac-Cit-YYRIK-NH ${ }_{2}$ & $<5$ & $<5$ \\
\hline Ac-RYY-Cit-IK-NH ${ }_{2}$ & $6.63 \pm 0.2$ & $6.32 \pm 0.12$ \\
\hline Ac-Cit-YY-Cit-IK-ol & $<5$ & $<5$ \\
\hline Ac-Cit-YYRIK-ol & $<5$ & $<5$ \\
\hline Ac-RYY-Cit-IK-ol & $7.30 \pm 0.13$ & $7.39 \pm 0.15$ \\
\hline ClAc-RYYRIK-ol & $8.35 \pm 0.29$ & $8.86 \pm 0.08$ \\
\hline Bz-RYYRIK-ol & $7.43 \pm 0.26$ & $7.78 \pm 0.23$ \\
\hline For-RYYRIK-ol & $8.00 \pm 0.11$ & $7.93 \pm 0.17$ \\
\hline Piv-RYYRIK-ol & $7.63 \pm 0.31$ & $7.52 \pm 0.12$ \\
\hline H-RYYRIK-ol & $6.39 \pm 0.06$ & $6.81 \pm 0.05$ \\
\hline Ms-RYYRIK-ol & $6.78 \pm 0.13$ & $6.80 \pm 0.18$ \\
\hline
\end{tabular}

each compound were sufficiently fitted according to the single-site binding model (fig. 1). Replacement of the arginine residue with citrulline (an uncharged natural $\alpha$-amino acid structurally similar to arginine) at first and/or fourth position resulted in decreases in affinities. This clearly indicates the importance of the positively charged arginine residue especially at the first position. The lower but still appropriate binding affinities show 
Table 2. $\left[{ }^{35} \mathrm{~S}\right] \mathrm{GTP} \gamma \mathrm{S}$-binding data, the stimulation of the G-proteins by the hexapeptides in membranes from rat brains and Chinese hamster ovary cells epressing human NOP receptor

\begin{tabular}{|c|c|c|c|c|}
\hline \multirow[t]{2}{*}{ Peptides } & \multicolumn{2}{|l|}{ Rat brain } & \multicolumn{2}{|l|}{$\mathrm{CHO}_{\mathrm{hNOP}}$} \\
\hline & $\mathrm{pEC}_{50} \pm \mathrm{SEM}$ & $\mathrm{E}_{\max }$ (Stim. \%) & $\mathrm{pEC}_{50} \pm \mathrm{SEM}$ & $\mathrm{E}_{\max }$ (Stim. \%) \\
\hline N/OFQ & $6.60 \pm 0.14$ & $100^{*}$ & $8.76 \pm 0.09$ & $100^{* *}$ \\
\hline Ac-RYYRIK-NH ${ }_{2}$ & ND & 70.9 & $8.36 \pm 0.18$ & 77.2 \\
\hline Ac-RYYRIK-ol & ND & 75.3 & $8.52 \pm 0.05$ & 80.8 \\
\hline Ac-RYY-Cit-IK-NH ${ }_{2}$ & ND & 78.4 & $6.81 \pm 0.04$ & 63.8 \\
\hline Ac-RYY-Cit-IK-ol & ND & 65.7 & $6.86 \pm 0.23$ & 49.5 \\
\hline ClAc-RYYRIK-ol & ND & 69.0 & $8.43 \pm 0.04$ & 49.4 \\
\hline Bz-RYYRIK-ol & ND & 61.9 & $7.06 \pm 0.22$ & 33.4 \\
\hline For-RYYRIK-ol & ND & 79.3 & $7.20 \pm 0.14$ & 53.2 \\
\hline Piv-RYYRIK-ol & ND & 66.9 & $7.19 \pm 0.07$ & 35.5 \\
\hline H-RYYRIK-ol & ND & 62.4 & $6.40 \pm 0.14$ & 30.0 \\
\hline Ms-RYYRIK-ol & ND & 68.9 & $6.55 \pm 0.18$ & 48.6 \\
\hline
\end{tabular}

$\mathrm{ND}=$ Not determined due to the shallow dose-response curves.

* In rat brain membranes the $\mathrm{E}_{\max }$ of N/OFQ was represented as $163 \%$ over the basal level (see fig. 2).

** In CHO-hNOP cell membranes the $\mathrm{E}_{\max }$ of $\mathrm{N} / \mathrm{OFQ}$ was represented as $670 \%$ over the basal level (see fig. 3).

that the exchange at the fourth position was more tolerable for retaining some affinity (fig. 1, left panel). The $\mathrm{N}$-terminal modifications of Ac-RYYRIK-ol led to compounds displaying lower affinities to the NOP receptor (fig. 1, right panel). The maximal number of binding sites $\left(B_{\max }\right)$ is calculated from the saturation binding experiments for membranes from rats $(290.4 \pm 12.03 \mathrm{fmol} / \mathrm{mg})$ and $\mathrm{CHO}_{\mathrm{hNOP}}(604.75 \pm 17.05 \mathrm{fmol} / \mathrm{mg})$. For the calculation of the $K_{i}$ values the following N/OFQ $K_{d}$ values were used; $0.514 \mathrm{~nm}$ for rat brain membranes and $0.625 \mathrm{~nm}$ for $\mathrm{CHO}_{\mathrm{hNOp}}$. The $\mathrm{pK}_{\mathrm{i}}$ values for the hexapeptides obtained in rat brain membranes and in $\mathrm{CHO}_{\mathrm{hNOP}}$ cell membranes are in good correlation $\left(\mathrm{r}^{2}=0.95\right)$.

\section{GTP $\gamma\left[{ }^{35} S\right]$ Binding}

The biochemical pharmacological parameters like potency $\left(\mathrm{EC}_{50}\right)$ and efficacy $\left(\mathrm{E}_{\max }\right)$ as well as the relative intrinsic activities of the hexapeptides were determined on crude membranes from rat brains and $\mathrm{CHO}$ cells expressing human NOP receptor. Data obtained with the analogues were compared to those of N/OFQ which is a full agonist at NOP receptor. All the hexapeptides exhibited weak to moderate stimulations of the G-proteins on rat brain membranes indicating their partial agonist properties. The maximal stimulation $\%\left(\mathrm{E}_{\max }\right)$ and the potency $\left(\mathrm{pEC}_{50}\right)$ of the ligands are summarized in table 2 . Among the hexapeptides, the high-affinity NOP receptor ligand Ac-RYYRIK-ol had a low enough intrinsic activity to be used as an antagonist in the GTP $\gamma\left[{ }^{35} \mathrm{~S}\right]$ binding experiments. The hexapeptide alcohol was tested on rat brain membranes for antagonist potency $\left(\mathrm{pA}_{2}\right)$ by its ability to antagonize the N/OFQ stimulated G-protein activation with Schild plot analysis (fig. 2). Ac-RYYRIK-ol competitively antagonized $\left(\mathrm{pA}_{2}=8.67\right)$ the N/OFQ stimulated G-protein activation. On the other hand, all the hexapeptides tested could stimulate GTP $\gamma\left[{ }^{35} \mathrm{~S}\right]$ binding on $\mathrm{CHO}_{\mathrm{hNOP}}$ with high efficacy thus behaving as partial agonists (see table 2 for $\mathrm{pEC}_{50}$ and $\mathrm{E}_{\max }$ values). The $\mathrm{pEC}_{50}$ values of the hexapeptides in the GTP $\gamma\left[{ }^{35} \mathrm{~S}\right]$ binding experiments are in good correlation with the $\mathrm{pK}_{\mathrm{i}}$ values of the hexapeptides obtained from the receptor binding experiments $\left(\mathrm{r}^{2}=0.90\right)$. Not surprisingly, the purported antagonist Ac-RYYRIK-ol behaved almost as an agonist N/OFQ with a similar potency and efficacy. UFP-101, a well-known peptide antagonist of the NOP receptor, showed no intrinsic activity when applied in these cells to stimulate the G-protein activation (fig. 3).

\section{Mouse Vas Deferens Bioassay}

The antagonist potency $\left(\mathrm{pA}_{2}\right)$ value of hexapeptide alcohol on the mouse vas deferens was previously reported to be 8.46 [25]. N-terminally modified and Arg-Cit exchanged hexapeptides were also tested in mouse vas deferens. In an attempt to determine their agonistic activity, 

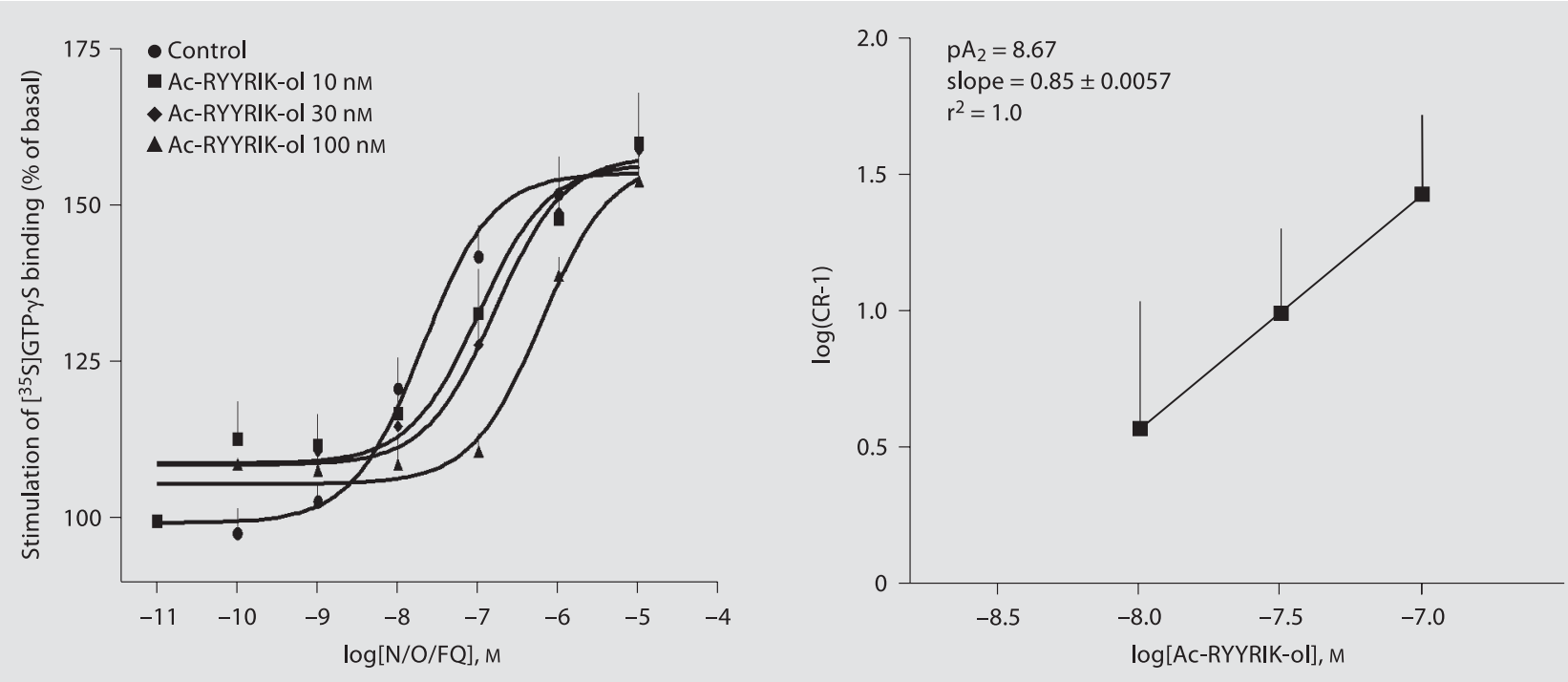

Fig. 2. Stimulation of $\left[{ }^{35} \mathrm{~S}\right] \mathrm{GTP} \gamma \mathrm{S}$ binding to rat brain membranes. Left panel: Concentration response curve of N/OFQ obtained in the absence (control) and presence of increasing concentrations of Ac-RYYRIK-ol (10$100 \mathrm{nM}$ ). On the right panel the corresponding Schild plot can be seen. Points represent the means \pm SEM of at least 3 separate experiments that were performed in triplicate.

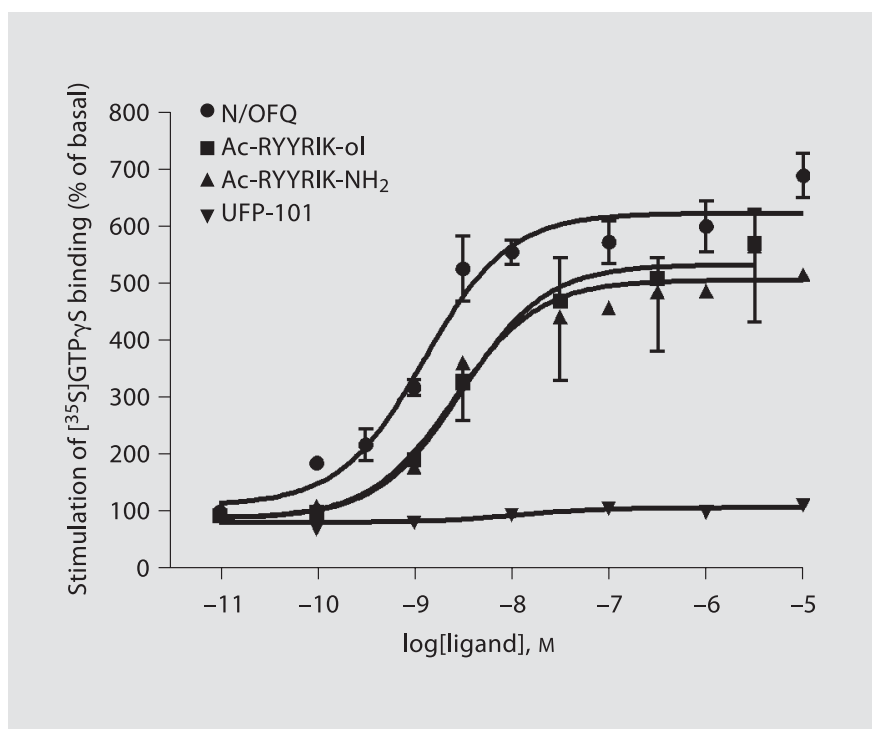

Fig. 3. Stimulation of $\left[{ }^{35} \mathrm{~S}\right] \mathrm{GTP} \gamma \mathrm{S}$ binding to membranes from $\mathrm{CHO}-\mathrm{NOPh}$. Stimulation is given as a percentage of the nonstimulated (basal) level. Basal activity (basal = 'total binding' - 'nonspecific binding') is taken as $100 \%$. Nonspecific binding is determined in the presence of $10 \mu \mathrm{M}$ unlabeled GTP $\gamma \mathrm{S}$. Incubations were carried out for $1 \mathrm{~h}$ at $30^{\circ} \mathrm{C}$ with gentle shaking. Points represent the means \pm SEM of at least three independent determinations each performed in triplicate. the modified hexapeptides were assessed for their ability to inhibit the twitch response to the electrical field stimulation. Only slight inhibition (always less than 50\% of control twitch) was recorded even at high concentrations (i.e. $1 \mu \mathrm{M}$ ). On the other hand, these compounds could antagonize the effect of N/OFQ on the mouse vas deferens at $1 \mu \mathrm{M}$ concentration (for ClAc-RYYRIK-ol at $100 \mathrm{~nm})$. Table 3 shows the antagonist potencies $\left(\mathrm{pK}_{\mathrm{B}}\right)$ of the modified hexapeptides and these potencies match well with the binding $\mathrm{K}_{\mathrm{i}}$ values.

\section{Discussion}

In this paper structure-activity studies of the hexapeptide Ac-RYYRIK- $\mathrm{NH}_{2}$, a NOP receptor ligand found in combinatorial peptide library [16], were summarized. Competition binding experiments with $\left[{ }^{3} \mathrm{H}\right] \mathrm{N} / \mathrm{OFQ}$ were performed in order to determine the equilibrium affinity constants of the modified hexapeptides and these compounds were further investigated on the GTP $\gamma\left[{ }^{35} \mathrm{~S}\right]$ binding assays to determine the pharmacological properties on membranes from rat brains and $\mathrm{CHO}$ cells expressing human NOP receptor. Among the hexapeptides, AcRYYRIK-ol displayed the highest affinity to the NOP receptor. In rat brain membranes the hexapeptide alcohol 
Table 3. Effects of the hexapeptides on the electrically stimulated mouse vas deferens

\begin{tabular}{|c|c|c|c|}
\hline \multirow[t]{2}{*}{ Peptides } & \multicolumn{2}{|l|}{ Agonist } & \multirow{2}{*}{$\begin{array}{l}\text { Antagonist } \\
\mathrm{pK}_{\mathrm{B}} \pm \mathrm{SEM}\end{array}$} \\
\hline & $\mathrm{pEC}_{50} \pm \mathrm{SEM}$ & $\mathrm{E}_{\max }$ (inhib. \%) & \\
\hline N/OFQ & $7.60 \pm 0.05$ & $90 \pm 5 \%$ & - \\
\hline Ac-RYY-Cit-IK-NH ${ }_{2}$ & \multicolumn{2}{|c|}{ variable agonist effect } & $6.34 \pm 0.21$ \\
\hline Ac-RYY-Cit-IK-ol & \multicolumn{2}{|c|}{ variable agonist effect } & $6.56 \pm 0.14$ \\
\hline ClAc-RYYRIK-ol & \multicolumn{2}{|c|}{ variable agonist effect } & $8.22 \pm 0.11$ \\
\hline Bz-RYYRIK-ol & \multicolumn{2}{|c|}{ variable agonist effect } & $6.05 \pm 0.3$ \\
\hline Piv-RYYRIK-ol & \multicolumn{2}{|c|}{ variable agonist effect } & $7.02 \pm 0.26$ \\
\hline H-RYYRIK-ol & \multicolumn{2}{|c|}{ variable agonist effect } & $6.05 \pm 0.25$ \\
\hline
\end{tabular}

was able to stimulate the G-proteins with a low efficacy; furthermore, the efficacy of the peptide was low enough to antagonize the N/OFQ stimulated G-protein activation. However, in membranes from $\mathrm{CHO}$ cells transfected with human NOP receptor, the hexapeptide alcohol showed a clear partial agonism with a high potency $\left(\mathrm{pEC}_{50}=8.52\right)$ and maximal stimulation of $541 \pm 83 \%$ over the basal level.

Structure-activity relationship studies were performed on analogues of Ac-RYYRIK-NH $\mathrm{H}_{2}$, principally on the Cand the $\mathrm{N}$-terminal of the hexapeptide, as well as targeting arginine residues within the sequence. C-terminal carboxyamide function was replaced with a hydroxymethylene moiety and yielded the novel hexapeptide, Ac-RYYRIK-ol. This hexapeptide was first reported to have antagonist properties based on GTP $\gamma\left[{ }^{35} \mathrm{~S}\right]$ binding experiments in rat brain membranes and mouse vas deferens bioassays [24]. However, subsequent in vitro and in vivo pharmacological characterization indicated that the hexapeptide alcohol is actually a low efficacy partial agonist [25]. The hexapeptide alcohol exhibited high affinity $\left(\mathrm{pK}_{\mathrm{i}} 9.39\right)$ to human NOP receptors expressed in $\mathrm{CHO}$ cells in radioligand binding assay. In the GTP $\gamma\left[{ }^{35} \mathrm{~S}\right]$ functional assays, the compound behaved as a potent agonist ( $\mathrm{pEC}_{50}$ 8.52) on membranes from $\mathrm{CHO}$ cells expressing the hNOP receptor. The effect of partial agonists can vary with the receptor density and coupling efficiency $[34,35]$. The stimulus-response efficiency of a system is dependent on the number of receptors as well as the relative stoichiometry between receptors and G-proteins, G-proteins and effectors, and further down the stimulus-response cascade $[35,36]$. In this study the $B_{\max }$ value of the $\mathrm{CHO}_{\mathrm{hNOP}}$ cells were approximately double of that of rat brain membranes. It has been already demonstrated that the pharmacological profile of low efficacy agonists like $\left[\mathrm{Phe}^{1} \psi\left(\mathrm{CH}_{2}-\mathrm{NH}\right) \mathrm{Gly}^{2}\right] \mathrm{N} / \mathrm{OFQ}(1-13)-\mathrm{NH}_{2}$ as well as that of Ac-RYYRIK-NH $\mathrm{N}_{2}$ can be changed to encompass full and partial agonism along with antagonism in the same cellular environment by altering, only one factor, NOP receptor density [34]. In our study the intrinsic activities of the ligands that were difficult to distinguish in the rat brain membranes were amplified in the $\mathrm{CHO}$ membranes abundantly expressing the hNOP receptor. In fact, this result is in line with our previous findings [25]. It was shown that in mouse colon tissues that are particularly useful for determining the residual agonist activity due to the high efficiency of the stimulus-response coupling, Ac-RYYRIK-ol behaved as a full agonist with a potency of 8.80 [25]. However, on the rat brain membranes the hexapeptide competitively antagonized the N/OFQstimulated G-protein activation with a $\mathrm{pA}_{2}$ value of 8.67. Similar results were observed on the mouse vas deferens tissues, where the hexapeptide behaved as a competitive antagonist with a $\mathrm{pA}_{2}$ value of 8.46 [25]. The hexapeptide alcohol was also shown to be effective in vivo, mimicking the N/OFQ effects on the tail withdrawal, food intake, and locomotor activity tests. Thus Ac-RYYRIK-ol is a potent, low efficacy NOP receptor partial agonist which can serve as a valuable pharmacological tool [25].

The newly synthesized acetylated peptide alcohol possesses two positively charged Arg (R) and two aromatic Tyr (Y) residues. For understanding the role of the charged Arg residues, replacement of Arg with Cit at first and/or fourth position was done. In the binding studies $\mathrm{Arg}^{1}$ residue at position 1 turned out to be essential for NOP receptor activation. Our finding is in line with the result obtained by Ala-scanning of Ac-RYYRIK-NH $\mathrm{NH}_{2}$ [37]. N/OFQ also contains two arginine side chains, at $\mathrm{Arg}^{8}$ and $\mathrm{Arg}^{12}$. The $\mathrm{Arg}^{8} / \mathrm{Ala}$ replacement produced a decreased functional potency and receptor affinity [38]. Although it is feasible to assume that the hexapeptides interact in a similar manner (i.e. with the negatively charged side chains of EL of the NOP receptor) as N/OFQ, it has been shown by photo-affinity labeling that the 
hexapeptides actually interact with a region within the Cterminus of the TM-II in NOP receptor: aa 107-113 (GlnGly-Thr-Asp-Ile-Leu-Leu), whereas N/OFQ interacts with the region of NOP receptor: aa 296-302 (Thr-AlaVal-Ile-Leu-Arg), spanning the C-terminus of EL-III and the N-terminus of transmembrane helix VII $[39,40]$.

Since none of the citrulline-replaced hexapeptides showed higher affinities than the parent peptide, it can be concluded that both $\mathrm{Arg}^{1}$ and $\mathrm{Arg}^{4}$ play an important role in the biological activity. Complete loss of the affinity in the case of $\mathrm{Cit}^{1}$ replaced peptides proves the critical role of $\mathrm{Arg}^{1}$. Our results confirms the findings by Kawano et al. [37] indicating the importance of the $\operatorname{Arg}^{1}$ by residual $\mathrm{N}$-terminal truncation.

The N-terminal acetyl group of the hexapeptide alcohol was modified further to determine its role in the binding process and to determine to which extent its elimination or subtitution with other moieties is tolerated in terms of biological activity. The $\mathrm{N}$-acetyl group was replaced by several substitutions with the following properties: (1) chloro-acetyl- or pivaloyl group that increases the steric hindrance; (2) mesyl group that increases steric hindrance and changes the character of the attached amide group; (3) benzoyl group that increases steric hindrance and confers an aromatic feature, furthermore it permits protonation; (4) formyl group that decreases the steric hindrance, and provides more hydrogen bond forming ability, and (5) free amino-terminal $\left(\mathrm{H}_{2} \mathrm{~N}-\right)$ that eliminates steric hindrance and well restores the basic character to the $\mathrm{N}$-terminal.

Deacetylated hexapeptide structure exhibited the lowest affinity towards the receptor and this peptide had the minimum intrinsic agonist activity as well. The substitution by the bulky pivaloyl (trimethylacetyl) group was less tolerated than expected, but on the other hand the intrinsic activity was lowered with these replacements. Among the polar group-bearing peptides the chloroacetylated compound displayed the best affinity. The complete change of the $\mathrm{N}$-terminal character with the mesyl substitution resulted in decreased potency. As a consequence, the $\mathrm{N}$-terminal protection with a polar group turned out to be important. $\mathrm{N}$-acetyl-arginine group is essential for eliciting the molecular contact or interaction with the receptor.

The novel analogues of the hexapeptide alcohol exhibited low antagonist potencies on the mouse vas deferens when tested with single concentration to antagonize the inhibition elicited by N/OFQ.

Considering the possible physiological role of NOP receptor partial agonists it has recently been shown to pro- duce functionally selective effects on cardiovascular and renal function in conscious rats [41]. Moreover, NOP partial agonists and antagonists have shown to have less effect than the agonists on the internalization of hNOP receptor [42] thus it is expected for the partial agonists to induce less tolerance [42]. Especially the partial agonist hexapeptides can induce G-protein coupling and the signal transduction with less or no significant receptor desensitization. This is most probably due to their different interaction with the NOP receptor.

As a conclusion, the chemical modifications of Ac-RYYRIK- $\mathrm{NH}_{2}$ yielded novel compounds having partial agonist properties. The substitution of the carboxyamide function at the C-terminal with a hydroxymethylene yielded a hexapeptide alcohol, Ac-RYYRIK-ol with high affinity to NOP receptor. The substitution of the $\mathrm{N}$-terminal with various acyl groups clearly emphasized the necessity of a polar group to protect the $\mathrm{N}$-terminal with an acetyl group. The positively charged Arg residues both at first and fourth positions are important requirements for the biological activity; in particular, the first position is crucial for ligand-receptor interaction.

Finally, the most interesting compound appeared to be the hexapeptide alcohol, Ac-RYYRIK-ol. The pharmacological action of this peptide was reported to be highly dependent on the tissue/assay; however, this analogue was very potent and effective in vivo. This compound can be a valuable research tool in the field of the N/OFQ-NOP receptor system as a selective, potent partial agonist with in vivo effects and stability similar to those of N/OFQ.

\section{Acknowledgements}

The authors would like to thank Dr. Remo Guerrini for his critical comments. This work was supported by grants from the National Office for Research and Technology (NKTH) RET2004-DNT (S.B., A.B.), Budapest, Hungary, from the Ministry of Education, Medichem-II, OM-00421/2004 (A.M.) Budapest, Hungary; partial supports were provided by funds from the University of Ferrara, Italy (60\% grant to G.C.). Ö.G. holds a Federation of European Biochemical Societies (FEBS) collaborative experimental scholarship for Central and Eastern Europe. 


\section{References}

-1 Mollereau C, Parmentier M, Mailleux P, Butour JL, Moisand C, Chalon P, Caput D, Vassart G, Meunier JC: ORL1, a novel member of the opioid receptor family: cloning, functional expression and localization. FEBS Lett 1994;341:33-38.

-2 Meunier JC, Mollereau C, Toll L, Suaudeau C, Moisand C, Alvinerie P, Butour JL, Guillemot JC, Ferrara P, Monsarrat B, Mazarguil H, Vassart G, Parmentier M, Costentin J: Isolation and structure of the endogenous agonist of opioid receptor-like ORL1 receptor. Nature 1995;377:532-535.

$\checkmark 3$ Reinscheid RK, Nothacker HP, Bourson A, Ardati A, Henningsen RA, Bunzow JR, Grandy DK, Langen H, Monsma FJ Jr, Civelli O: Orphanin FQ: a neuropeptide that activates an opioid-like $G$ protein-coupled receptor. Science 1995;270:792-794.

$\checkmark 4$ Civelli O, Nothacker HP, Reinscheid R: Reverse physiology: discovery of the novel neuropeptide, orphanin FQ/nociceptin. Crit Rev Neurobiol 1998;12:163-176.

$\checkmark 5$ Mollereau C, Mouledous L: Tissue distribution of the opioid receptor-like (ORL1) receptor. Peptides 2000;21:907-917.

6 Calo G, Guerrini R, Rizzi A, Salvadori S, Regoli D: Pharmacology of nociceptin and its receptor: a novel therapeutic target. Br J Pharmacol 2000;129:1261-1283.

$\checkmark 7$ Mogil JS, Pasternak GW: The molecular and behavioral pharmacology of the orphanin $\mathrm{FQ} /$ nociceptin peptide and receptor family. Pharmacol Rev 2001;53:381-415.

$\checkmark 8$ Zaveri N: Peptide and nonpeptide ligands for the nociceptin/orphanin FQ receptor ORL1: research tools and potential therapeutic agents. Life Sci 2003;73:663-678.

-9 Marti M, Mela F, Fantin M, Zucchini S, Brown JM, Witta J, Di Benedetto M, Buzas B, Reinscheid RK, Salvadori S, Guerrini R, Romualdi P, Candeletti S, Simonato M, Cox BM, Morari M: Blockade of nociceptin/orphanin FQ transmission attenuates symptoms and neurodegeneration associated with Parkinson's disease. J Neurosci 2005;25: 9591-9601.

-10 Carra G, Rizzi A, Guerrini R, Barnes TA, McDonald J, Hebbes CP, Mela F, Kenigs VA, Marzola G, Rizzi D, Gavioli E, Zucchini S, Regoli D, Morari M, Salvadori S, Rowbotham DJ, Lambert DG, Kapusta DR, Calo G: [(pF)Phe4,Arg14,Lys15]N/OFQ-NH2 (UFP102), a highly potent and selective agonist of the nociceptin/orphanin FQ receptor. J Pharmacol Exp Ther 2005;312:1114-1123.

-11 Jenck F, Wichmann J, Dautzenberg FM, Moreau JL, Ouagazzal AM, Martin JR, Lundstrom K, Cesura AM, Poli SM, Roever S, Kolczewski S, Adam G, Kilpatrick G: A synthetic agonist at the orphanin FQ/nociceptin receptor ORL1:anxiolytic profile in the rat. Proc Natl Acad Sci USA 2000;97: 4938-4943.
12 Calo G, Guerrini R, Rizzi A, Salvadori S, Burmeister M, Kapusta DR, Lambert DG, Regoli D: UFP-101, a peptide antagonist selective for the nociceptin/orphanin FQ receptor. CNS Drug Rev 2005;11:97-112.

13 Calo G, Rizzi A, Rizzi D, Bigoni R, Guerrini R, Marzola G, Marti M, McDonald J, Morari M, Lambert DG, Salvadori S, Regoli D: [Nphe1,Arg14,Lys15]nociceptin-NH2, a novel potent and selective antagonist of the nociceptin/orphanin FQ receptor. Br J Pharmacol 2002;136:303-311.

14 Ozaki S, Kawamoto H, Itoh Y, Miyaji M, Azuma T, Ichikawa D, Nambu H, Iguchi T, Iwasawa $\mathrm{Y}$, Ohta $\mathrm{H}$ : In vitro and in vivo pharmacological characterization of J-113397, a potent and selective non-peptidyl ORL1 receptor antagonist. Eur J Pharmacol 2000; 402:45-53.

15 Zaratin PF, Petrone G, Sbacchi M, Garnier M, Fossati C, Petrillo P, Ronzoni S, Giardina GA, Scheideler MA: Modification of nociception and morphine tolerance by the selective opiate receptor-like orphan receptor antagonist (-)-cis-1-methyl-7-[[4-(2,6-dichlorophenyl)piperidin-1-yl] methyl]-6,7, 8,9-tetrahydro-5H-benzocyclohepten-5-ol (SB-612111). J Pharmacol Exp Ther 2004; 308:454-461.

${ }_{16}$ Dooley CT, Spaeth CG, Berzetei-Gurske IP, Craymer K, Adapa ID, Brandt SR, Houghten RA, Toll L: Binding and in vitro activities of peptides with high affinity for the nociceptin/orphanin FQ receptor, ORL1. J Pharmacol Exp Ther 1997;283:735-741.

17 Thomsen C, Valsborg JS, Platou J, Martin J, Foged C, Johansen NL, Olsen UB, Madsen K: $\left[{ }^{3} \mathrm{H}\right]$ ac-RYYRWK-NH$H_{2}$, a novel specific radioligand for the nociceptin/orphanin FQ receptor. Arch Pharmacol 2000;362:538545.

18 Judd AK, Kaushanskaya A, Tuttle DJ, Sanchez A, Khroyan T, Polgar W, Toll L: N-terminal modifications leading to peptide ORL1 partial agonists and antagonists. J Pept Res 2003;62:191-198.

19 Judd AK, Tuttle DJ, Jones RW, Sanchez A, Polgar W, Berzetei-Gurske I, Toll L: Structure-activity studies on high affinity NOPactive hexapeptides. J Pept Res 2004;64:8794.

20 Ishiama K, Tereda T, Oyama T, Ohgi T: Peptide derivatives and medicinal compositions. 2001; WO 01/079263.

21 Kapusta DR, Thorkildsen C, Kenigs VA, Meier E, Vinge MM, Quist C, Petersen JS: Pharmacodynamic characterization of ZP120 (Ac-RYYRWKKKKKKK-NH2), a novel, functionally selective nociceptin/orphanin FQ peptide receptor partial agonist with sodium-potassium-sparing aquaretic activity. J Pharmacol Exp Ther 2005;314: 652-660.
22 Larsen BD, Petersen JS, Harlow K, Kapusta DR: Novel peptide conjugates. 2001;WO 01/98324.

23 Rizzi A, Rizzi D, Marzola G, Regoli D, Larsen BD, Petersen JS, Calo G: Pharmacological characterization of the novel nociceptin/orphanin FQ receptor ligand, ZP120: in vitro and in vivo studies in mice. Br J Pharmacol 2002; 137:369-374

24 Kocsis L, Orosz G, Magyar A, Al-Khrasani M, Kato E, Ronai AZ, Bes B, Meunier JC, Gunduz O, Toth G, Borsodi A, Benyhe S: Nociceptin antagonism: probing the receptor by $\mathrm{N}$-acetyl oligopeptides. Regul Pept 2004;122:199-207.

25 Gunduz O, Rizzi A, Baldisserotto A, Guerrini R, Spagnolo B, Gavioli EC, Kocsis L, Magyar A, Benyhe S, Borsodi A, Calo G: In vitro and in vivo pharmacological characterization of the nociceptin/orphanin FQ receptor ligand Ac RYYRIK ol. Eur J Pharmacol 2006;539:39-48.

26 Toth G, Kramer M, Sirokman F, Borsodi A, Ronai A: Preparation of 7,8,19,20-H-3 naloxone of high specific activity. J Label Comp Radiopharm 1982;19:1021-1030.

27 Soucek M, Urban J, Saman D: Preparation of $\mathrm{N}$-protected alpha-amino alcohols by acetoxyborohydride reduction of $\mathrm{N}$-protected alpha-amino-acid esters. Coll Czech Chem Commun 1990;55:761-765.

28 Orosz G, Kiss LP: Simple and efficient synthesis of 2-chlorotritylchloride resin. Tetrahedron Lett 1998;39:3241-3242.

29 Ligeti M, Gunduz O, Magyar A, Kato E, Ronai AZ, Vita C, Varga I, Hudecz F, Toth G, Borsodi A, Benyhe S: Synthesis and biological studies of nociceptin derivatives containing the DTPA chelating group for further labeling with therapeutic radionuclides. Peptides 2005;26:1159-1166.

30 Bradford MM: Rapid and sensitive method for quantitation of microgram quantities of protein utilizing principle of protein-dye binding. Anal Biochem 1976;72:248-254.

>31 Calo G, Rizzi A, Bogoni G, Neugebauer V, Salvadori S, Guerrini R, Bianchi C, Regoli D: The mouse vas deferens: a pharmacological preparation sensitive to nociceptin. Eur J Pharmacol 1996;311:R3-5.

>32 Cheng Y, Prusoff WH: Relationship between the inhibition constant (K1) and the concentration of inhibitor which causes 50 per cent inhibition (I50) of an enzymatic reaction. Biochem Pharmacol 1973;22:3099-3108.

33 Arunlakshana O, Schild HO: Some quantitative uses of drug antagonists. Br J Pharmacol Chemother 1959;14:48-58.

34 McDonald J, Barnes TA, Okawa H, Williams J, Calo G, Rowbotham DJ, Lambert DG: Partial agonist behaviour depends upon the level of nociceptin/orphanin FQ receptor expression: studies using the ecdysone-inducible mammalian expression system. Br J Pharmacol 2003;140:61-70. 
35 Kenakin T: How Different Tissues Process Drug Response; in: A Pharmacology Primer. Theory, Application, and Methods. Amsterdam, Elsevier Academic Press, 2003, pp 1735.

36 Harrison C, Traynor JR: The [35S] GTP gamma $S$ binding assay: approaches and applications in pharmacology. Life Sci 2003;74: 489-508.

37 Kawano C, Okada K, Honda T, Nose T, Sakaguchi K, Costa T, Shimohigashi Y: Structural requirements of nociceptin antagonist AcRYYRIK-NH2 for receptor binding. J Pept Sci 2002;8:561-569.
38 Reinscheid RK, Ardati A, Monsma FJ Jr, Civelli O: Structure-activity relationship studies on the novel neuropeptide orphanin FQ. J Biol Chem 1996;271:14163-14168.

>39 Mouledous L, Topham CM, Mazarguil H, Meunier JC: Direct identification of a peptide binding region in the opioid receptorlike 1 receptor by photoaffinity labeling with [Bpa(10),Tyr(14)]nociceptin. J Biol Chem 2000;275:29268-29274

40 Bes B, Meunier JC: Identification of a hexapeptide binding region in the nociceptin (ORL1) receptor by photo-affinity labelling withAc-Arg-Bpa-Tyr-Arg-Trp-Arg- $\mathrm{NH}_{2}$. Biochem Biophys Res Commun 2003;310: 992-1001.
41 Kapusta DR, Burmeister MA, Calo G, Guerrini R, Gottlieb HB, Kenigs VA: Functional selectivity of nociceptin/orphanin FQ peptide receptor partial agonists on cardiovascular and renal function. J Pharmacol Exp Ther 2005;314:643-651.

42 Corbani M, Gonindard C, Meunier JC: Ligand-regulated internalization of the opioid receptor-like 1: a confocal study. Endocrinology 2004;145:2876-2885. 